\title{
一般街路への迁回交通を考慮した都市高速道路の交通制御に関する検討* \\ An Analysis of Effects of Traffic Control on Urban Expressways Considering the Influences to Surface Roads*
}

小川 圭一**・秋山 孝正***

By Keiichi OGAWA** and Takamasa AKIYAMA***

\section{1. はじめに}

都市高速道路の交通管理をおこなう場合、高速道路本 線上の交通状況のみならず、周辺の一般街路への迁回交 通による影響を考慮する必要がある。そのため、交通管 理の検討をおこなうための涉滞シミュレーションにおい ては、一般街路への迁回交通量の算定についても考慮す る必要がある。

本研究では、阪神高速道路堺線を対象とした渋滞シミ ユレーションをもとに、周辺の一般街路への迂回交通量 を評価するためのモデルの拡張をおこなう。具体的には、 都市高速道路の流入制御による一般街路への迂回交通量 の変化をオンランプの流入待ちスペースをもとに算定す る。これを交通量配分により得られた一般街路網の交通 量に加算することにより、一般街路での所要時間の変化 を算定する。

これにより、都市高速道路の交通制御方法の検討にお いて、一般街路の交通状況への影響を評価できるモデル の拡張をおこなう。さらに作成されたモデルを用いて、 オンランプでの流入制御方法による高速道路本線上およ び周辺の一般街路への影響の分析をおこなう。これによ り、作成されたモデルの検証をおこなう。

\section{2. 都市高速道路の渋帯シミュレーション}

\section{（1）渋滞シミュレーションモデルの概要}

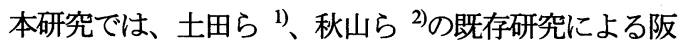
神高速道路の渋滞シミュレーションに組み込むことを前 提に、一般街路への影響を考慮するためのモデルの拡張 をおこなう。ここではまず、前提となる既存研究の啮滞 シミュレーションについて示す。

対象路線は、阪神高速道路堺線上り（堺集約料金所一

\footnotetext{
* キーワード : 交通管理, 交通制御, 交通流, 渋滞シミュレーション

** 正会員, 博(工学), 立命館大学理工学部環境システム工学科 講師 テ525-8577 滋賀県草津市野路東 1-1-1 TEL: 077-561-5033, FAX: 077-561-2667

*** 正会員, 工博, 岐阜大学工学部社会基盤工学科 教授 テ501-1193 岐阜県岐阜市柳戸 1-1 TEL: 058-293-2443, FAX: 058-230-1528
}

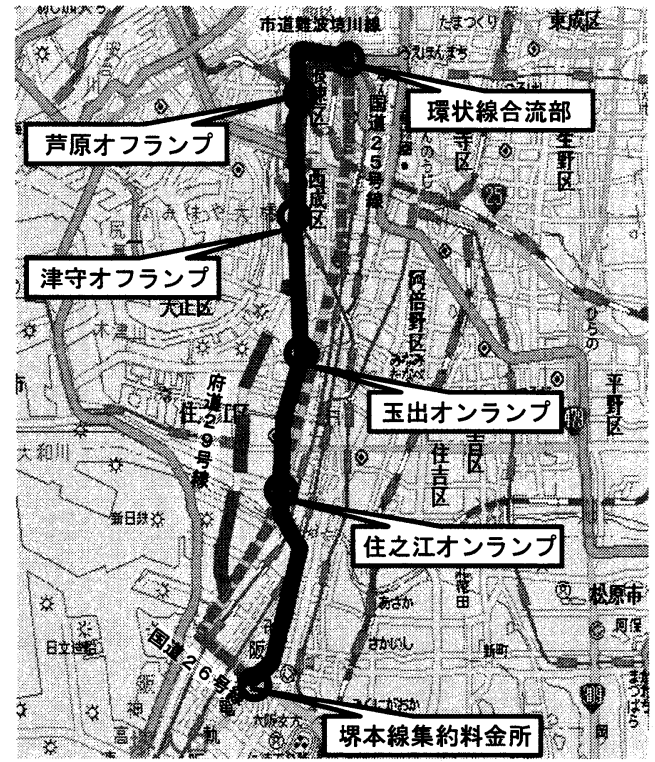

図-1 対象路線周辺の道路網

環状線合流部間 : 全長 $11.9 \mathrm{~km})$ である。堺線は、堺市 安井町を起点とし、大阪市の中心部である浪速区湊町で 阪神高速道路環状線に接続している。堺市など大阪府南 部の郊外と大阪市都心部とを結ぶ主要道路の 1 つである。 対象路線周辺の道路網を図-1に示す。

シミュレーションモデル上では、路線を $500 \mathrm{~m}$ ごとに 24 の区間に分割し、各区間の交通密度の時間的な変化 を推計することにより、路線の動的な交通現象の推計を おこなっている。計算方法は、単位時間（本モデルでは 20 秒) ごとに上流区間から下流区間に流れる車両台数 を求める、ブロック密度法と呼ばれるものである。ここ で、区間ごとの車両移動台数は、上流区間の流出需要交 通量と下流区間の受け入れ可能交通量との関係から求め られる。また、区間ごとの交通特性を表すため、車両検 知器による計測データにもとづき各区間に交通密度一速 度関係（K-V 関係）を定め、これにもとづいて各区間 の走行速度を算定している。これにより、各ランプでの 流入交通量、流出交通量を入力変数として、本線上の交 通渋滞状況、流入車両の本線走行時間、料金所での待ち 時間などを推定することができる。

なお、具体的な渋滞シミュレーションモデルの詳細に 
ついては、参考文献 1),2)を参照されたい。

\section{（2）各種パラメータの設定}

上述の渋滞シミュレーションの演算をおこなうには、 多くのパラメータについて適切な值を設定する必要があ る。ここでは、シミュレーションの現況再現性を考慮し ながら、試行錯誤によって以下のように各種パラメータ の設定をおこなっている。

\section{(a) 密度一速度特性}

各区間の密度一速度特性については、車両検知器によ る計測値にもとづき線形関数によって設定した。

ここでは、対象路線内の路線形状の相違を考慮して、 対象路線を「堺一芦原間」「芦原一環状線合流部間」

「環状線」「住之江・玉出合流部」に分類し、4 種の密 度一速度特性を設定した。具体的には、既存研究にもと づいて表-1 のような密度一速度特性を設定した ${ }^{2)}$ 。

\section{(b) 料金所の交通処理時間}

対象路線では、堺本線集約料金所、住之江オンランプ、 玉出オンランプの各々について、ランプ形状および大型 車混入率などが異なっている。そのため、各オンランプ での平均交通処理時間も異なるものになっている。ここ では、既存研究にもとづいてそれぞれ 5.0 秒（堺本線集 約料金所）、6.5 秒（住之江料金所）、6.0 秒（玉出料金 所）と設定した2)。

\section{（c）下流端の流出可能交通量}

対象路線下流端での流出可能交通量は、車両検知器の 計測值にもとづいて設定している。しかしながら、車両 検知器で 4 車線 8,000[台/h]程度の交通量を観測した場合、 $3 \%$ 程度の観測誤差が生じることが既存調査により報告 されている。そのため、現況再現性を高めるためにパラ メータの再設定をおこない、時間帯に応じて観測值に倸 数を乗じた值を設定している。

\section{(d) オフランプの分畦率}

本モデルでは、オフランプの流出交通量を決定するた めに分岐率を用いている。ここでは、オフランプと分岐 点上流における断面交通量の計測值をもとに、5 分間ご との分岐率を設定している。

\section{（3）現況再現性の確認}

対象日時を平成 9 年 10 月 14 日（火）午前 6:00〜 10:55 として、シミュレーションによる 5 分間ごとの渋 滞状況の変化を推計することにより、現況再現性の確認 をおこなった。各料金所での開ロブース数は、現実の交 通制御パターンにあわせて、午前 6:00〜6:55 が堺本線 集約料金所 5 ブース、住之江オンランプ 2 ブース、玉出 オンランプ 2 ブース、午前 7:00〜10:55 が堺本線集約料 金所 3 ブース、住之江オンランプ 1 ブース、玉出オンラ ンプ1ブースとしている。なお、当日の交通状況は平日
表-1 各区間のK-V 特性の設定

\begin{tabular}{ccc}
\hline 区間 & $\begin{array}{c}\text { 自由速度 } \\
{[\mathrm{km} / \mathrm{h}]}\end{array}$ & $\begin{array}{c}\text { 飽和密度 } \\
{[\text { [台/ } \mathrm{km}]}\end{array}$ \\
\hline 堺一玉出間 & 75 & 97 \\
\hline 玉出一環状線合流部間 & 85 & 97 \\
\hline 環線 & 75 & 97 \\
\hline 住之江·玉出合流部 & 65 & 99 \\
\hline
\end{tabular}

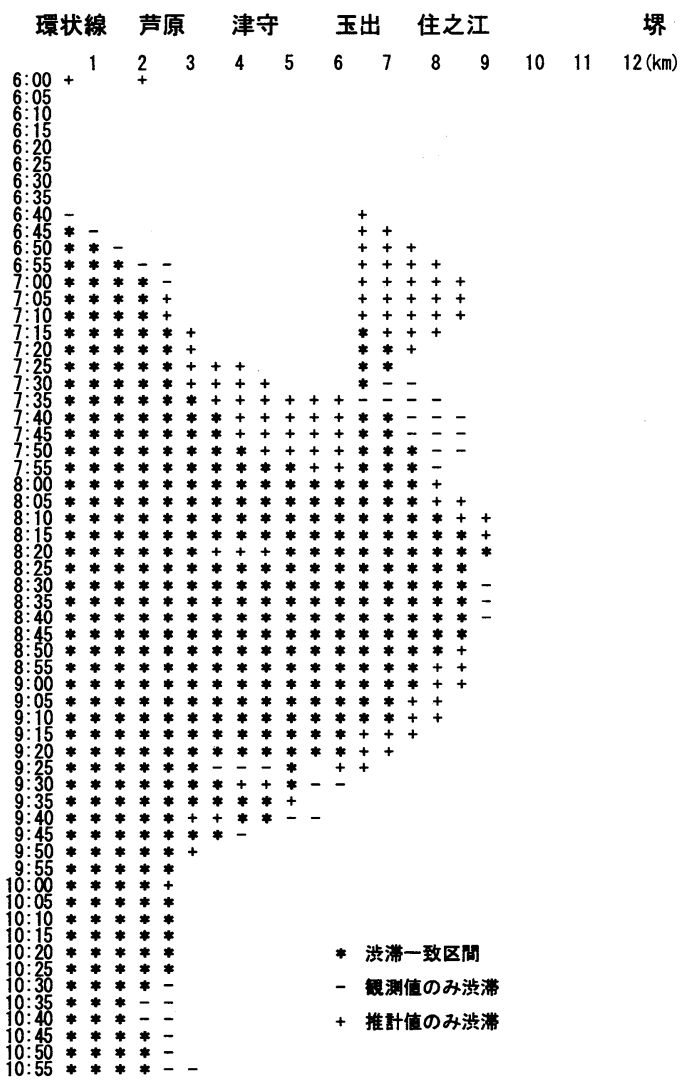

図-2 渋滞シミュレーションによる現況再現

の平均的な交通状況であった。

渋滞シミュレーションによる渋滞状況の推計值と実測 值を比較すると、図-2 のようになる。なお、ここでの 「渋滞」とは、区間の走行速度が $30 \mathrm{~km} / \mathrm{h}$ 以下となる状 況を指している。ここで、渋滞シミュレーションの再現 精度を渋滞判定の適合率を用いて評価すると、

$$
\begin{aligned}
\text { 適合率 } & =\frac{(\text { 渋滞判定一致数 })}{(\text { 対象時間数 }) \times(\text { 対象区間数 })} \\
& =\frac{1305}{60 \times 24}=0.906
\end{aligned}
$$

となる。

渋滞シミュレーションの推計結果を実測值と比較する と、環状線合流部を先頭とする渋滞の発生、解消状況や、 
最大渋滞長については良好に再現されている。しかしな がら、玉出オンランプを先頭とする渋滞は実測值よりも 30 分ほど早期に発生、解消されている。また、環状線 合流部を先頭とする橴滞に関しては、推計值の方が午前 7 時台における渋滞延伸速度が速く、ピーク時間帯以降 の渋滞解消がやや遅いといえる。そのため、オンランプ 合流部を含むモデル構造の設定については、さらなる改 善が必要であると考えられる。

このように、推計結果には多少の誤差があるものの、 対象路線全体としては渋滞シミュレーションの現況再現 性は良好であると確認することができる。

\section{3. 一般街路への影響の算定方法}

\section{（1）高速道路網・一般街路網の設定}

渋带シミュレーションを用いて都市高速道路の交通制 御の分析をおこなうには、高速道路本線上の交通状況の みならず、周辺の一般街路への迁回交通を含めた、都市 道路網を対象にした検討が必要である。そこで具体的な 迁回経路として、阪神高速道路堺線とほぼ並行している 国道 26 号線・国道 25 号線および府道大阪和泉泉南線 (府道 29 号線）・市道難波境川線を取り上げる。これ らの対象道路の概要は図-1に示した通りである。

\section{(a) 道路ネットワーク}

まず、阪神東地区の道路網を対象に交通均衡分析をお こない、1 時間ごとの一般街路の交通量、平均速度を求 めることとする。ここでは、安田ら ${ }^{3)}$ の既存研究を参考 に、上述の迁回経路を含めた阪神東地区の高速道路、一 般街路の道路ネットワークを作成した。

一般街路については主要幹線道路を中心としたネット ワーク表現をおこなった。作成した道路ネットワークを 図-3 に示す。ここで、口印のノードはセントロイドを 示す。一方、阪神高速道路のネットワークを図-4 に示 す。オンランプ、オフランプに位置するノードでは、一 般街路ネットワークと接続している。この結果、一般街 路がノード数 101、リンク数 364、高速道路がノード数 142、リンク数 276、合計でノード数 243、リンク数 640 の道路ネットワークを用いることとする。また阪神高速 道路のオンランプは 60 箇所、オフランプは 58 䇢所とな っている。

\section{(b) OD 交通量}

$\mathrm{OD}$ 交通量の設定は、平成 6 年度全国道路交通センサ スのデータ (高速道路・一般街路の両者)をもとにおこ なっている。

ただし、このデータは 24 時間交通量の数值であるた め、時閒帯ごとの交通量の比率を設定し、分配する必要 がある。ここでは、別途調查されている大阪地区におけ る阪神高速道路の時間交通量の 24 時間交通量に対する

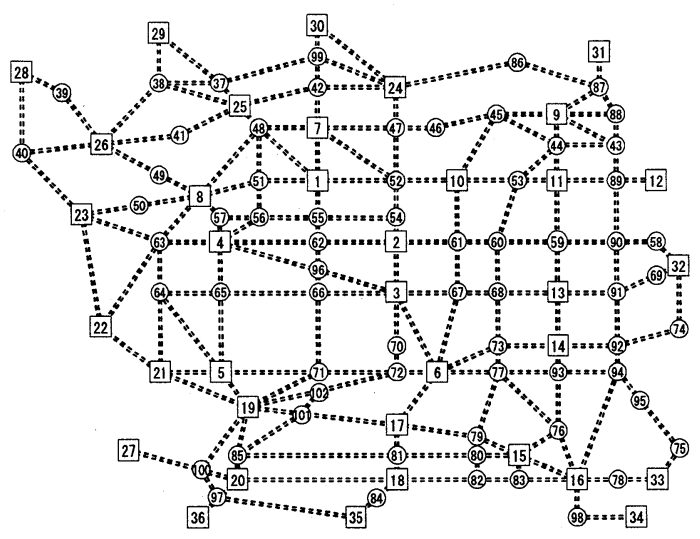

図-3 一般街路のネットワーク

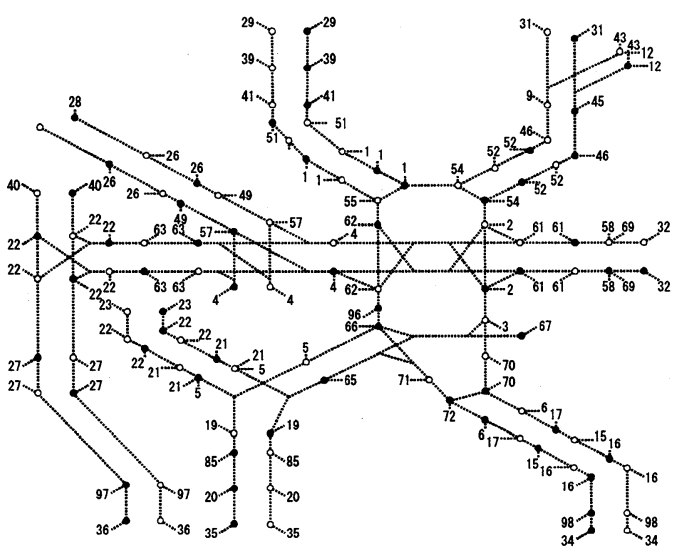

図-4 阪神高速道路のネットワーク

比率をもとに、 1 時間ごとの OD 交通量を設定した ${ }^{4)}$ 。 具体的には、24 時間交通量に対する比率を、午前 6 時 台 : $3.5 \%$, 午前 7 時台 : $6.9 \%$, 午前 8 時台 : $6.5 \%$, 午 前 9 時台 : $6.2 \%$, 午前 10 時台 : $6.2 \%$, 午前 11 時台： $5.7 \%$ としている。これらにより、午前中のピーク時間 帯の表現をおこなっている。

なお、現実には都市高速道路における交通量の時間帯 別の比率と、一般街路も含めたすべての交通量の時間帯 別の比率とが完全に一致しているわけではない。ここで は都市内交通の OD にあっても比較的長距離のトリップ を対象とした分析であるため、それほど大きな違いはな いものと考え、上記の仮定を置いた。ただし、厳密には パーソントリップ調査などのデータを用いて OD ごとの 時間帯別の比率を検証する必要があると考えられる。

\section{(c) リンクデータ}

リンクパフォーマンス関数には BPR 関数を用いた。 各リンクのパラメータ值は、阪神高速道路配分システム において設定された Q-V ランク值にもとづいて設定し ている。また、高速道路料金については、時間価値 
80[円/分·台]を用いて所要時間に置き換え、オンランプ 該当リンクの所要時間に付加している。

これらの設定をもとに、高速道路・一般街路をあわせ た道路ネットワーク上での時間帯別の交通量配分をおこ ない高速道路・一般街路の各リンクの交通量および平 均速度を算定する。これにより、高速道路リンクの交通 量も推定できることから、時間帯ごとの都市高速道路に 対する利用予定交通量も算定できることになる。

\section{（2）一般街路への迁回交通量の算定}

つぎに、都市高速道路の渋滞シミュレーションをもと に、一般街路への迂回交通量の算定をおこなう。ここで、 一般街路への迁回交通量は、オンランプ上流側の料金所 待ちスペースの長さを待ち行列長が超過したときに、到 着した車両がすべて一般街路へ迁回するものと仮定した。 まず、阪神高速道路堺線における各オンランプの料金 所許容待ち台数を、入口近傍の道路構造を考慮して設定 する。堺集約料金所では、安井町交差点からの入口と、 第二阪和道路からの入口とに分かれている。各々の許容 待ち行列長は、安井町からの入口が $400 \mathrm{~m}$ 、第二阪和道 路からの入口が $1,200 \mathrm{~m}$ と設定した。同様に、住之江才 ンランプの許容待ち行列長は $300 \mathrm{~m}$ 、玉出オンランプの 許容待ち行列長は $500 \mathrm{~m}$ と設定した。これらの許容待ち 行列長と、待ち行列における平均車頭距離をもとに、各 オンランプの許容待ち台数を設定する。ここでは、大型 車の平均車両長を $8.90 \mathrm{~m}$ 、普通車の平均車両長を $4.97 \mathrm{~m}$ 、 平均車間距離を $2.50 \mathrm{~m}$ と設定している。また、大型車 混入率は実測值をもとに、堺集約料金所、住之江オンラ ンプ、玉出オンランプをそれぞれ 0.27、0.42、0.31 と設 定する ${ }^{5}$ 。

これらの設定により、シミュレーションにより求めら れる単位時間ごとの待ち行列長をもとに、一般街路への 迂回交通量を算定する。また阪神高速道路への流入交通 量は、迁回交通量に相当する量を減じることとする。

なお、ここでの迁回交通量に関する仮定は、各ランプ の料金所待ちスペースという物理的な制約条件のみから 設定している。現実的に、待ち行列長が待ちスペースを 超過した場合には一般街路内に退避できるスペースがあ るわけではないので、超過した後に到着した車両は一般 街路に迂回せざるを得ない状況にあるため、これ自体は 妥当な仮定であると考えられる。ただし、現実的なドラ イバーの経路選択行動の要因としては、オンランプ付近 には各種の洂滞情報が提示されているため、物理的な制 約条件以外の要因にも依存している。既存調査としては、 自然渋滞、事故渋滞などの渋滞長情報の大きさに応じて ドライバーの迂回率が変化していることがわかっている ため、これらをもとに経路選択行動モデルを作成し、本 分析と組み合わせることが考えられる。
算定された一般街路への迁回交通量を 1 時間ごとに集 計し、前節(b)で規定した交通量配分における時間帯別 交通量に加算する。これを用いて交通量配分をおこなう ことにより、迂回交通を考慮した一般街路各リンクの交 通量、所要時間を算定する。一方、迂回交通が発生する 分、本線への流入交通量は減少するため、高速道路本線 上の交通状況も変化することになる。

\section{（3）現況再現結果}

ここでは、現況 OD 交通量にもとづきシミュレーショ ンと交通量配分をおこなった場合の結果をみる。

まず、このモデルによる現況再現の精度についてみる ため、上記の手順による各リンクの交通量の推計結果を、 道路交通センサス（一般交通量調査）における該当地点 の観測結果と比較した。対象道路網全体でのリンク交通 量の相関係数をとると 0.783 となり、比較的良好な值と なった。ただし、観測值については時間帯ごとの值が得 られているわけではないので、24 時間交通量の観測値 を先述の仮定により時間帯ごとの比率で分配した值を用 いている。したがって、本来の意味での時間帯ごとの現 況再現性の確認ができているわけではない。

また、個々のリンクでの推計値の傾向をみると、都市 道路網全体としては高速道路の交通量がやや過大に推計 されていること、また対象地域付近では、出発地となる 堺オンランプ付近での交通量がやや過小に推計されてい ることなどの傾向がある。これらの理由としては、ネッ トワーク表現において現実の道路網を簡略化して表現し ていること、また高速道路と一般街路の区別においては 高速道路料金を時間価值 80[円/分·台]を用いて所要時間 に置き換えていることなどが考えられ、精度向上には簡 略化の方法、その際のリンクデータの設定方法、時間価 值の設定值の検討などが必要であると考えられる。

つぎに、阪神高速道路と一般街路との交通状況の比較 をおこなう。

阪神高速道路堺線と一般街路（ルート 1 : 国道 26 号 線・国道 25 号線、ルート 2 : 府道大阪和泉泉南線・市 道難波境川線）の 1 時間ごとの平均所要時間の比較を 図-5 に示す。午前 6 時台は道路網全体の交通量が少な いため、一般街路がルート 1、ルート 2 とも 30 分強で あるのに対して、高速道路を利用した場合は約 14 分で 到着する。ところが午前 7 時台に入ると、交通量が急増 するため、高速道路、一般街路とも午前 6 時台に比べて 所要時間は約 2 倍を要している。午前 8 時台以降は交通 量が緩やかに減少するので、平均所要時間は高速道路、 一般街路とも徐々に減少に向かっている。

図-6 は、このときの 1 時間ごとの平均走行速度の変 化を示したものである。午前 6 時台では高速道路が $54 \mathrm{~km} / \mathrm{h}$ 、一般街路が $20 \mathrm{~km} / \mathrm{h}$ 強の平均速度で走行してい 
るが、午前 7 時台に入ると高速道路、一般街路ともに走 行速度が急激に減少している。午前 8 時台では、高速道 路本線上が渋滞しているため平均走行速度がさらに減少 している。一方、一般街路では少しではあるが、走行速 度の回復がみられる。午前 9 時台以降は、一般街路の平 均走行速度が少しずつの増加であるのに対し、高速道路 は走行速度の回復が早く、午前 11 時台には午前 6 時台 とほぼ同じ走行速度になっている。

このように、時間帯ごとの交通量の変化にともなう都 市高速道路、一般街路の交通状況の変化を推計すること ができることになる。

\section{4. 流入制御方法による影響の比較}

\section{（1）対象制御方法}

ここでは、構築した渋滞シミュレーションを用いて、 都市高速道路の流入制御を対象に、交通制御方法による 影響の検討をおこなう。流入制御は、高速道路本線上の 渋滞が発生した場合、オンランプにおいて流入交通量を 制限することにより交通渋滞の緩和を図るものである。

しかしながら、流入交通量を制限することにより料金所 での待ち行列が延伸することから、一般街路にも影響を 及ぼすことになる。このため現実的な制御においては一 般街路への影響を考慮しながらおこなう必要がある。こ こでは、各々の制御方法が高速道路本線上の交通状況に 及ぼす影響をみるとともに、一般街路への影響評価もお こなう。比較対象とする流入制御は、武居らのの既存研 究で提案されている以下の方法である。

[制御 0] 基本ケース（制御なし）：ケース間比較のた めの基本ケースとする。

[制御 1] 入路閉鎖ブース制限方式（現行制御方式）： 渋滞の延伸に応じて、制御対象入路と開ロブース数 を設定した制御要領にもとづき、制御対象入路の開 ロブース数を減少させる。

以下の 3 種の方法は入路流入調整方式と呼ばれる。こ れは、入路閉鎖ブース制限方式を基本としたブースごと の制御率にもとづいて、ブースを開放した状態で流入す る車両の流入間隔を調節する方式である。現在導入が進 められている ETC ブースおよびETC 車載器搭載車の普 及により、このような制御方法も技術的に可能となると 考えられる。具体的には、ブースの開閉時間の調整や、 ブースでの信号制御（ランプメータリング）などが考え られる。入路流入調整方式には、制御率の算定方法の違 いにより、以下の 3 パターンが検討されている》。

[制御 2-1] 入路流入調整方式 $1:$ 全制御対象入路で制 御率を算定するが、許容待ち台数を超えた場合は当 該入路の制御を解除寸る。

[制御 2-2］入路流入調整方式 2 : 全制御対象入路で制

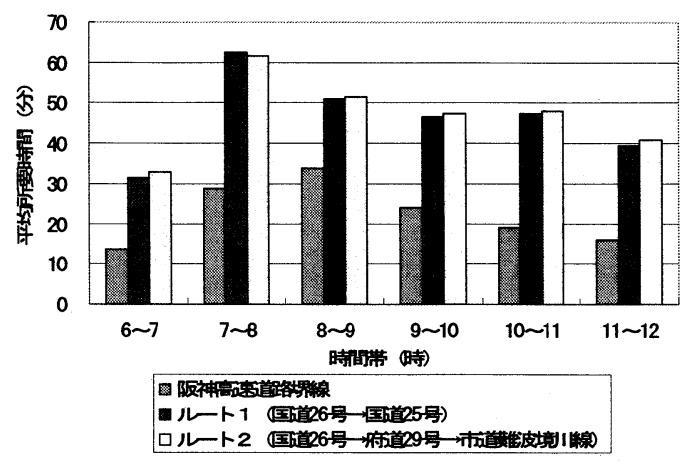

図-5 都市高速道路と一般街路の所要時間の比較

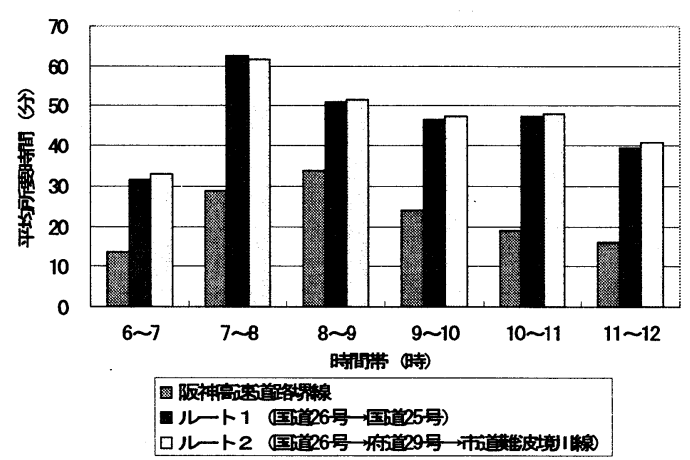

図-6 都市高速道路と一般街路の平均走行速度の比較

御率を算定し、許容待ち台数を超えた場合でも制御 を継続する。

[制御 2-3] 入路流入調整方式 $3:$ 許容待ち台数を超過 しない入路のみで制御率を算定する。許容待ち台数 を超えた場合は当該入路の制御を解除するが、制御 を解除した場合、他の入路に対して必要な流入量を 満たす制御率を設定する。

\section{（2）高速道路本線上の交通状況}

つぎに、構筑したシミュレーションを用いて、流入制 御方法による影響の比較をおこなう。

まず、各流入制御方法による渋滞状況の推計結果から、 高速道路本線上の最大渋滞長、渋滞細続時間、渋滞量を 算定し、表-2に示す。ここで、渋滞量とは 5 分間ごと の走行速度の推計值をもとに、渋滞時間と涉滞距離との 積をとったものである。これは、阪神高速道路で用いら れている交通渋滞指標の1つとなっている。なお、ここ での「橴滞」とは、区間の走行速度が $30 \mathrm{~km} / \mathrm{h}$ 以下とな る状況を指している。

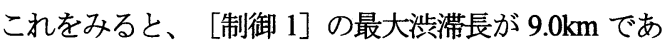
るのに対し、[制御 2-1］は $11.5 \mathrm{~km} 、$ [制御 2-3］は $10.0 \mathrm{~km}$ と、最大渋滞長が増加していることがわかる。 一方 [制御 2-2] は、料金所の許容待ち台数が超過した 場合にも制御を継続するので、橴滞継続時間が他の制御 
方法に比べて短く、最大渋滞長も $6.5 \mathrm{~km}$ と対象制御方 法の中で最も短くなっている。また渋滞量については、

[制御 1] は 23.0[km·h] [ [制御 0] の 49.0[km·h]に比 較して半分以下となっている。また [制御 2-2］を実施 した場合が $15.8[\mathrm{~km} \cdot \mathrm{h}]$ と最小であるが、［制御 2-1］と [制御 2-3］を実施した場合には、逆に［制御 1］より も増加していることがわかる。

うぎに、各流入制御方法による車両 1 台あたりの所要 時間の時系列的変化を図-7 に示す。ここで所要時間は、 本線上の所要時間と料金所での待ち時間の和で表される。 本線上の所要時間は、堺本線集約料金所を 5 分ごとに出 発する車両の環状線合流部までの所要時間である。ここ では、 5 分ごとの変化が最も大きい午前 7 時台、午前 8 時台の所要時間の比較を示す。最大となる所要時間を

[制御 1］と比較すると［制御 2-1］では微増し、［制 御 2-3］ではやや減少している。また [制御 2-2] では [制御 1] に比較して約 10 分の減少となっている。

また、各流入制御方法による時間帯ごとの平均走行速 度の比較を図-8 に示す。午前 6 時台はどの制御方法に ついも走行速度は $50 \mathrm{~km} / \mathrm{h}$ 程度であるが、午前 7 時台 以降には走行速度が大きく低下し、制御方法による走行 速度の違いが顕著となっている。とくに [制御 1] と

[制御 2-2］の場合には、平均走行速度が他の制御方法 に比べて大きくなっている。

以上のことから、最も高速道路本線上の渋滞が緩和さ れるのは [制御 2-2］であり、[制御 1] も渋滞緩和に 一定の効果を発揮することがわかる。しかしながら、こ こでの流入制御効果が大きいほど、料金所待ち台数が増 加し、一般街路への迁回交通量が増加しているものと考 えられる。

\section{（3）一般街路の交通状況への影響}

まず、前章で述べた方法により、時間帯ごとの迁回交 通量を算定した結果を図-9 に示す。なお、ここでは各 オンランプの迁回交通量の合計值を示している。これを みると、［制御 1] が対象時間帯全体にわたって迁回交 通が発生しているのに対して、入路流入調整方式では午 前 7 時台に集中して迂回交通が発生している傾向がみら れる。また [制御 1] と比較すると、[制御 2-1] が 134 台の減少、[制御 2-3］が 3 台の増加とそれほど大 きな違いがないのに対し、［制御 2-2］は252 台の迁回 交通量の増加が見込まれている。

つぎに、都市高速道路、一般街路それぞれについて、 すべての車両の総走行時間を制御方法ごとに比較する。 これを図-10 に示す。制御方法によって高速道路上の総 走行時間は大きく変動しているのに対し、一般街路の総 走行時間の変化は微小であることがわかる。このため、 対象道路網を総合的にみると、全体的には流入制御方法
表-2 最大渋滞長、渋滞継続時間、渋滞量の比較

\begin{tabular}{|c|c|c|c|c|}
\hline & \multirow{2}{*}{$\begin{array}{l}\text { 涉滞葘 } \\
{[\mathrm{km} \cdot \mathrm{h}]}\end{array}$} & \multicolumn{2}{|c|}{ 涉滞継続時間 [h:m] } & \multirow{2}{*}{$\begin{array}{c}\text { 最大渋滞長 } \\
{[\mathrm{km}]}\end{array}$} \\
\hline & & 発生時刻 & 解消時刻 & \\
\hline \multirow{2}{*}{ 制御 0} & \multirow{2}{*}{49.0} & \multicolumn{2}{|c|}{$5: 15$} & \\
\hline & & $6: 40$ & $11: 55$ & 11.5 \\
\hline \multirow{2}{*}{ 制御 1} & \multirow{2}{*}{23.0} & \multicolumn{2}{|c|}{$5: 00$} & \\
\hline & & $6: 40$ & $11: 40$ & 9.0 \\
\hline \multirow{2}{*}{ 制御 2-1 } & \multirow{2}{*}{35.8} & \multicolumn{2}{|c|}{$5: 10$} & 15 \\
\hline & & $6: 45$ & $11: 55$ & 11.5 \\
\hline \multirow{2}{*}{ 制御 2-2 } & \multirow{2}{*}{15.8} & \multicolumn{2}{|c|}{$4: 55$} & 5 \\
\hline & & $6: 45$ & $11: 40$ & 0.0 \\
\hline \multirow{2}{*}{ 制御 2-3 } & \multirow{2}{*}{30.6} & \multicolumn{2}{|c|}{ 5:10 } & 10 \\
\hline & & $6: 45$ & $11: 55$ & 10.0 \\
\hline
\end{tabular}

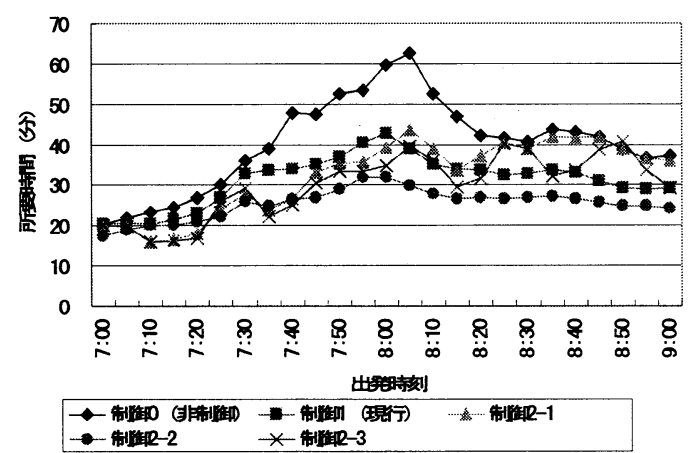

図-7 車両 1 台当たりの所要時間の比較

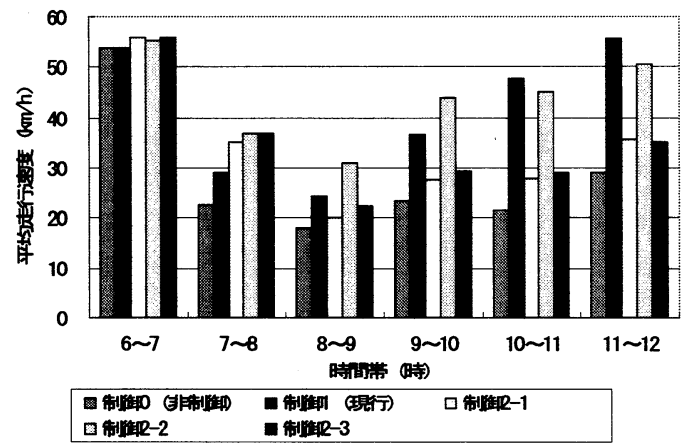

図-8 時間带ごとの平均走行速度の比較

の違いが一般街路に及ぼす影響は、高速道路本線上に及 ぼす影響に比べれば小さいことがわかる。たとえば［制 御 1] と［制御 2-1］を比較すると、高速道路本線上の 総走行時間は 6,747[台·h] 敒 8,273[台·h] に大きく増加 しているのに対し、一般街路の総走行時間は 14,248[台· h]から 14,166[台·h]とわずかな减少にとどまっているこ とがわかる。

また流入制御方法による都市高速道路、一般街路の総 走行台キロの比較をしたものを図-11 に示す。これをみ ると、[制御 1] と比較して [制御 2-2］のみが総走行 台キロが増加していることがわかる。ここで、総走行時 間の比較においては [制御 1] より増加していた [制御 
2-3］が、総走行台キロでは減少していることがわかる。 これは迁回交通量の増加による一般街路の混雑が [制御 2-3] の方が激しく、走行速度の低下が大きかったため と考えられる。また、[制御 1] と [制御 2-3］を比較 すると、迂回交通量の総計はほぼ同じ台数でありながら、 時間帯ごとの分布の違いによって総走行台キロに変化が 生じていることがわかる。

ただし、ここでは都市内の一般街路網のうち堺市と大 阪市都心部とを結ぶ代表的な 2 経路のみを取り上げて比 較しているため、一般街路網全体に対する影響としては 過小評価になっている可能性が高い。迁回交通量の影響 はここでの 2 経路上のリンクのみでなく、交通量配分に よって周辺の他のリンクにも波及している。したがって、 一般街路網すべてに対する影響をみるには、この 2 経路 上のリンク以外の交通状況、他の OD 交通量の所要時間 に対する影響も含めて検討する必要がある。ただし、本 研究では都市高速道路の交通制御を検討することを主目 的としており、一般街路については交通制御による負荷 を検討できるようにすることを目的としたため、広範囲 の影響についての詳細な検討はおこなっていない。

また、本研究のモデルでは都市高速道路上は動的なシ ミュレーション、一般街路は静的な交通量配分という組 み合わせによって交通状況が算定されている。またこの ため、都市高速道路上は 5 分単位、一般街路は 1 時間単 位と、異なる時間単位で交通状況が算定されている。そ のため一般街路では 5 分単位での詳細な交通状況の変化 による影響が相殺されてしまい、この点においても相詨 的に影響が過小に評価されていることが考えられる。

\section{（4）対象道路網の全体評価}

まず [制御 0] の場合と比較すると、いずれの制御方 法も高速道路本線上の総走行時間が減少していることか ら、制御効果を有していることがわかる。とくに現行の 制御方法である [制御 1] は、高い制御効果を有してい ることがわかる。しかしながら、[制御 1] はブースの 開閉によって制御をおこなう方式のため、本線上の交通 状況を常に反映した制御とはいえず、時間帯によっては 過㮃に制御がおこなわれている場合も存在する。

当然のことながら、どのような評価指標を重視するか によって最適な流入制御方法は異なってくる。本研究の 結果によれば、迁回交通量による一般街路への影響を少 なくするには [制御 2-1］が適しており、都市高速道路 への流入交通量を増加させながら本線上の渋滞緩和を図 るには [制御 2-3］が適している。都市高速道路と一般 街路の所要時間の総和で判断するなら、本研究の検討範 囲においては [制御 2-2］が最小であり、最も制御効果 を発揮しているといえる。

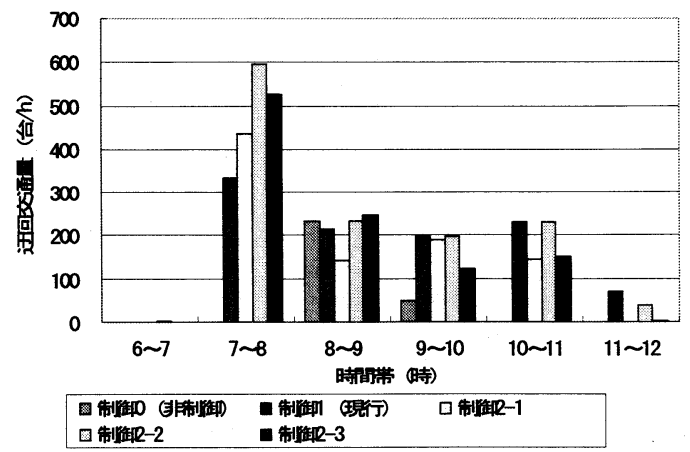

図-9 時間帯ごとの迁回交通量の比較

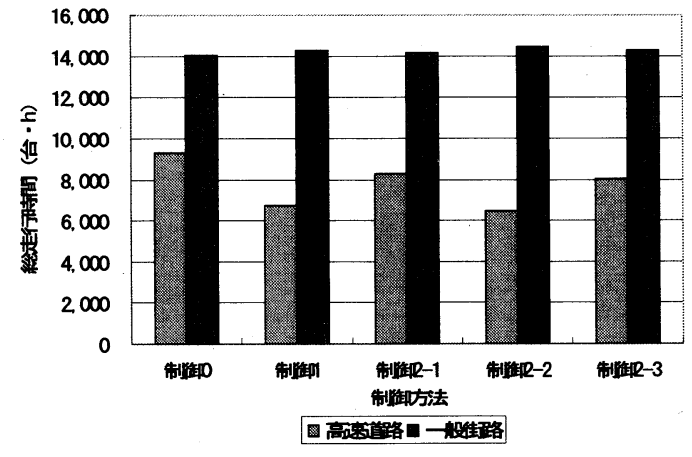

図-10 高速道路・ 一般街路の総走行時間の比較

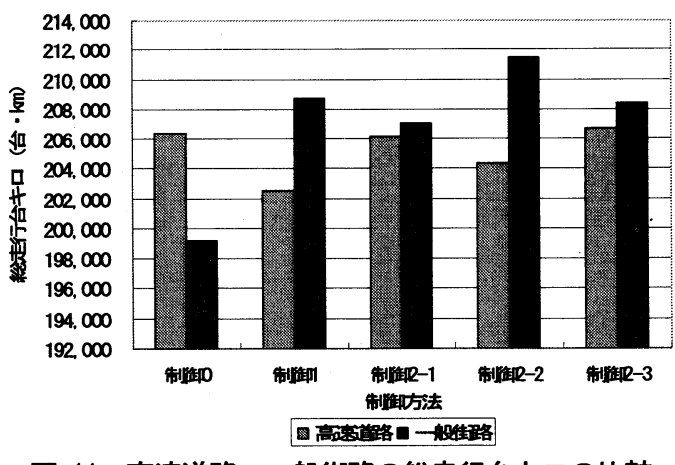

図-11 高速道路・一般街路の総走行台キロの比較

\section{5. おわりに}

本研究では、都市高速道路の流入制御などの交通制御 方法を反映し、都市道路網全体での評価が可能な渋滞シ ミュレーションの拡張をおこなった。さらに、作成した モデルを用いてオンランプでの流入制御方法による都市 高速道路、一般街路への影響の比較をおこなった。本研 究の成果としては、以下の諸点が挙げられる。

(1) 都市高速道路を対象とした渋滞シミュレーションに 対し、一般街路への影響を評価するためのモデルの 拡張をおこなった。これにより、都市高速道路の交 通制御による影響を、一般街路を含めて評価できる 
ようになった。

(2) 構築したモデルを用いて、都市高速道路の流入制御 方法にもとづく高速道路本線上および周辺の一般街 路への影響を分析した。これにより、流入制御方法 の違いによる本線上および一般街路への影響の違い を明らかにすることができた。

今後の課題としては、以下の諸点が挙げられる。

(1) 本研究では料金所で許容待ち台数を超えた交通量が すべて一般街路へ迁回するものと仮定したが、現実 的には必ずしもそうではないと考えられる。そのた め、本線上の交通状況や待ち行列長に応じた呼損率 の設定や、都市高速道路を利用するか否かを選択す る利用者の経路選択行動を内生化したモデルの拡張 をおこなうことが考えられる。

(2) 本研究のモデルでは都市高速道路上は動的なシミュ レーション、一般街路は静的な交通量配分という組 み合わせによって交通状況が算定されている。また このため、都市高速道路上は 5 分単位、一般街路は 1 時間単位と、異なる時間単位で交通状況が算定され ている。そのため一般街路では 5 分単位での詳細な 交通状況の変化による影響が相殺されてしまい、相 対的に影響が過小に評価されていることが考えられ る。両者をあわせて適切に影響を評価するためには、 静的、動的といった異なる方法の組み合わせによる 影響を考慮した、本モデル全般についての構成の改 良をおこなうことが必要と考えられる。たとえば、
交通量配分に関しても時間帯別配分などの時間軸を 考慮した方法の導入が考えられる。

\section{謝辞}

本研究の計算、プログラム作成に当たっては、岐阜大学工学 部学生 (現・名古屋市役所勤務) 山本具教氏にご協力いただい た。ここに記して感謝の意を申し上げる。またデータの収集に 当たっては、阪神高速道路公団、株式会社都市交通計画研究所 にご協力いただいた。あわせて感謝の意を申し上げる。

\section{参考文献}

1) 土田貴義, 横山剛士, 秋山孝正 : 輆滞シミュレーションを 用いた交通管理支援システムの構築, 土木計画学研究・論 文集, No.16, pp.879-886, 1999.

2) 秋山孝正, 土田貴義, 小川圭一 : 個別車両挙動を考慮した 都市高速道路の渋滞シミュレーションの構築, 土木学会論 文集, No.702/IV-55, pp.103-115, 2002.

3) 安田幸司, 大藤武彦, 秋山孝正 : 高速道路乗り継ぎ制の適 用性に関する検討, 土木計画学研究・論文集, No.13, pp.893-900, 1996.

4) 阪神高速道路公団 : 第 17 回阪神高速道路起終点調查報告書, 1985.

5) 阪神高速道路公団, (社) 交通工学研究会: 阪神高速道路の 交通渋滞対策に関する調查研究報告書, 1982.

6) 阪神高速道路公団 : Traffic Control System 阪神高速の交通管 制システム, 1997.

7) 武居克兒, 雪本雄彦, 奥嶋政嗣, 大藤武彦 : 都市高速道路 における流入調整方式による入路制御手法の評価, 第 21 回 交通工学研究発表会論文報告集, pp.233-236, 2001.

\section{一般街路への迁回交通を考慮した都市高速道路の交通制御に関する検討}

小川 圭一・秋山 孝正

都市高速道路の交通管理をおこなう場合、都市高速道路上の交通状態のみならず、周辺の一般街路への 迁回交通による影響を考慮する必要がある。本研究では、阪神高速道路堺線を対象とした渋滞シミュレー ションをもとに、周辺の一般街路への迁回交通を評価するためのモデルの挔張をおこなった。具体的には、 都市高速道路の流入制御による一般街路への迁回交通量の変化をオンランプの流入待ちスペースをもとに 算定し、これを交通量配分により得られた一般街路網の交通量に加算することにより、一般街路での所要 時間の変化を算定した。これにより、都市高速道路の交通制御方法の検討において、一般街路の交通状況 への影響を評価することを可能とした。

\section{An Analysis of Effects of Traffic Control on Urban Expressways Considering the Influences to Surface Roads}

By Keiichi OGAWA and Takamasa AKIYAMA

It is necessary to take into consideration the influences to surface road conditions in considering the traffic control on urban expressways. In this research, traffic simulation model on Osaka-Sakai Route of Hanshin Expressway is extended for evaluating the effects of traffic control on urban expressways to surface road conditions. In this model, traffic volumes and travel times on surface road network are estimated by user equilibrium assignment with the detour traffic from urban expressway. Thereby, the effects of traffic control strategies on urban expressway can be evaluated within the urban road network using the constructed simulation model. 